\title{
The Effect of Household Appliances on Female Labor Force Participation: Evidence from Micro Data
}

\author{
Daniele Coen-Pirani* \\ Carnegie Mellon University \\ 5000 Forbes Avenue, Pittsburgh, PA 15213 U.S.A. \\ coenp@andrew.cmu.edu \\ Alexis León \\ University of Pittsburgh \\ 4530 Wesley W. Posvar Hall, Pittsburgh, PA 15260 \\ aleon@pitt.edu \\ Steven Lugauer \\ University of Notre Dame \\ 443 Flanner Hall Notre Dame, IN 46556 \\ slugauer@nd.edu \\ This version: September 10, 2008.
}

\begin{abstract}
We estimate the effect of household appliance ownership on the labor force participation rate of married women using micro-level data from the 1960 and 1970 U.S. Censuses. In order to identify the causal effect of home appliance ownership on married women's labor force participation rates, our empirical strategy exploits both time-series and cross-sectional variation in these two variables. To control for endogeneity, we instrument a married woman's ownership of an appliance by the average ownership rate for that appliance among single women living in the same U.S. state. Single women's labor force participation rates did not increase between 1960 and 1970. By our estimation, the diffusion of household appliances accounts for about forty percent of the observed increase in married women's labor force participation rates during the 1960's.
\end{abstract}

Keywords: Female labor supply, household appliances, home production.

JEL Classification: J22.

${ }^{*}$ Corresponding author. Fax: 1-412-268-7064. Phone: 1-412-268-6143. 


\section{Introduction}

In the last few decades women's labor force participation rates have increased dramatically, especially for married women. In 1950, about 25 percent of married women participated in the workforce; by 2000, nearly 60 percent of married women participated. An extensive literature has investigated the possible causes of this increase. ${ }^{1}$ Greenwood, Seshadri, and Yorukoglu (2005) [from now on GSY] argue that the diffusion of home appliances such as washing machines, freezers, etc. played an important role in "liberating" women from housework and in propelling them into the workforce. According to GSY, the adoption of time-saving technologies occurred because of a surge in the rate of technological progress in the home durable goods sector. Consequently, the quality-adjusted relative price of home appliances declined. Building on Becker (1965) and Gronau (1977), GSY develop a dynamic equilibrium model in which a household jointly determines female labor force participation and home appliance purchases. GSY calibrate a version of their model and show that the observed decline in the relative price of home appliances can explain about 50 percent of the increase in married women's labor force participation rates between 1900 and 1980 .

Despite the intuitive appeal of GSY's story and the quantitative results of their model, there is little independent empirical evidence in favor of their hypothesis. Moreover, from a theoretical perspective, improvements in the productivity of home durable goods could lead married women to increase rather than decrease their time allocated to housework. The sign of this effect depends on the elasticity of substitution between home and market goods in the household's utility function (Jones, Manuelli, and McGrattan, 2003).

\footnotetext{
${ }^{1}$ In addition to the "liberation hypothesis" discussed in this paper, other explanations for the increase in women's labor force participation include: 1. A reduction in fertility (Evans and Angrist, 1998) 2. The diffusion of the oral contraceptive (Goldin and Katz, 2002 and Wong, 2008) which reduced the pregnancyrelated uncertainty faced by young women enrolling in professional programs. 3. The indirect effect of WWII on men's attitudes toward working women (Fernandez, Fogli, and Olivetti, 2004) 4. The reduction in the gender wage gap (Smith and Ward, 1985; Jones, Manuelli, and McGrattan, 2003; Gayle and Golan, 2006). Albanesi and Olivetti (2007) develop a variant of the "liberation hypothesis", emphasizing the role of medical advances and the introduction of infant formula as catalysts that enabled married women to increase their participation in the workforce. Goldin (1990) provides a detailed historical account of women's experience in the labor market.
} 
The goal of this paper is to empirically test GSY's hypothesis using micro-level data on female labor force participation and household appliance ownership. The data comes from the 1960 and 1970 U.S. Census of the Population. In only those years, households were asked to provide information on their ownership of some home appliances (freezers, washers, and dryers) in addition to the standard demographic variables. Women's labor force participation rates and households' ownership of appliances both increased significantly during the 1960's. The labor force participation rate for white married women increased by 10 percentage points, and the fraction of households with all three of the appliances mentioned above increased from 11 to 28 percent (see Table 1 ).

In order to identify the causal effect of home appliance ownership on married women's labor force participation rates, our empirical strategy exploits time-series and cross-sectional variation in these two variables. Ordinary least squares (OLS) will not, in general, provide consistent estimates of the causal effect of appliance ownership on women's labor force participation because of the endogeneity of home appliance ownership. Instead, we employ an instrumental variable (IV) strategy by using the state-level ownership rate of an appliance among single women as an instrument for a married woman's ownership of that appliance.

We assume that the observed temporal and cross-sectional variation in single women's ownership of home appliances is driven by the (unobserved) appliance costs rather than by changes in women's labor force participation rates. Two key observations corroborate this assumption. First, differently from married women, the labor force participation rate of single women did not change appreciably from 1960 to 1970 (see Table 2). Second, the instruments based on single women's appliance ownership rates at the state level do not explain differential changes in single women's labor force participation rates across states and over time. The results also survive a number of other specification and robustness checks.

Our estimates, based on the identification strategy described above, provide strong empirical support for GSY's hypothesis. The diffusion of home appliances in the decade between 1960 and 1970 explains about forty percent of the observed increase in married women's 
labor force participation rates according to our results.

As far as we know, this paper is the first to use microdata on appliance ownership and female labor force participation to provide evidence on GSY's hypothesis. There is related work in both economics and sociology. In the economics literature, Cavalcanti and Tavares (2008) use country-level panel data for OECD countries for the period 1975-1999 to show the existence of a statistically significant relationship between the relative price of home appliances and female labor force participation rates across countries. Dinkelman (2008) considers the employment effects of household electrification in rural South Africa in the late 1990's. She uses a community's land gradient as an instrument for its treatment status and finds a positive effect of electrification on female employment. Cardia (2008) regresses county-level changes in female labor force participation rates between 1940 and 1950 on county-level adoption rates of bathtubs and refrigerators using data from the U.S. Census. She finds a positive association between the adoption of indoor plumbing facilities and female labor force participation rates. ${ }^{2}$ In addition to adopting a different identification strategy relative to these papers, our approach is based on microdata, and allows us to control at the individual level for the standard determinants of female labor force participation, such as household income, a woman's education, etc.

Sociologists have also studied the relationship between home technology and women's allocation of time to housework, sometimes reaching different conclusions than GSY. For example, Cowan (1983) considers the relationship between household technology and women's housework during the last two centuries in the U.S. and argues that the amount of time spent by the average American woman in housework in 1965 and at the beginning of the twentieth century are comparable in magnitude (see Cowan, 1983, page 199, for example). The lack of representative time-use data for the earlier part of the twentieth century makes

\footnotetext{
${ }^{2}$ Cortes and Tessada (2007) focus on increased immigration, as opposed to declining prices of home appliances, as a determinant of female labor supply. They observe that immigrants' labor often substitutes for female labor in home production (e.g. child care and housekeeping services) and find evidence that immigration affects the labor supply of high-skill native women.
} 
such comparisons difficult. Recent research by Roberts and Rupert (1995), Bianchi et al. (2000), and Aguiar and Hurst (2006) based on time-use surveys and the Michigan Panel Study on Income Dynamics clearly shows that the time allocated by women, and especially married working women, to home production has fallen considerably in the last 40 years. This trend is consistent with GSY's hypothesis. ${ }^{3}$

The rest of the paper is organized as follows. In Section 2 we introduce a simple model of home production and female labor supply, which is used to organize the discussion of the empirical evidence and of our identification strategy. In Section 3 we describe the Census data and present our main econometric results. Section 4 details several robustness checks and the results from alternative specifications. Section 5 concludes.

\section{A Simple Model and the Identification Strategy}

In this section we introduce a simple model of female labor supply meant to capture the essence of GSY's argument and to help explain our identification strategy.

\subsection{A Simple Model}

We start from the labor supply decision of a married woman in a household where preferences for consumption of a market $(c)$ and home-produced $(x)$ good are described by the following additively-separable utility function:

$$
U=u(c)+g(x)
$$

The functions $u$ and $g$ are strictly increasing, strictly concave, and differentiable.

In the household, the husband always works in the market and earns wage income $y$.

\footnotetext{
${ }^{3}$ In the sociology literature, also see the work by Bittman, Rice, and Wajcman (2004) who use a crosssection of micro-level time-use data from Australia in 1997 to study the association between time spent in different homework activities by men and women and their ownership of household appliances.
} 
If the woman works in the market she earns wage income $w \bar{h}$, where $w$ is the hourly wage and $\bar{h}$ is the exogenous number of hours worked. ${ }^{4}$ Her endowment of time per period is normalized to one. There is no leisure in the model. The home good $x$ is produced using a woman's non-market time $1-\bar{h}$ and units of household capital (appliances), denoted by $k$. The household can obtain home capital at a unit rental rate of $q$. The production function for the home good can be written as:

$$
x=f\left(1-\bar{h} I^{w}, k\right),
$$

where $I^{w}$ equals one if the woman works in the market and zero otherwise. We assume $f$ is strictly increasing in its two arguments, concave in $k$, and such that $f_{k}(1, k)>f_{k}(1-\bar{h}, k)$, i.e. the marginal product of home capital increases with a woman's time allocated to home production. Below we discuss additional restrictions on $f$ necessary to capture GSY's link between appliance prices and married women's labor force participation.

The household maximizes utility (equation 1 ) by choosing $c, k$, and whether the woman works in the market, subject to the home-production function (2) and the household's budget constraint:

$$
c=y+w \bar{h} I^{w}-q k .
$$

Replacing the budget constraint (3) into the objective function allows us to eliminate $c$ and write the first-order condition with respect to $k$ as:

$$
u^{\prime}\left(y+w \bar{h} I^{w}-q k\right) q=g^{\prime}\left(f\left(1-\bar{h} I^{w}, k\right)\right) f_{k}\left(1-\bar{h} I^{w}, k\right) .
$$

Denote the optimal choice of appliances that satisfies equation (4) by $k^{\mathrm{m}}$ :

$$
k^{\mathrm{m}}=K\left(q, y, I^{w}\right)
$$

\footnotetext{
${ }^{4}$ We focus on labor force participation as the measure of a woman's labor supply in our empirical analysis. Section 4.3 considers alternative outcome variables.
} 
For a given labor force participation decision $I^{w}$, it is straightforward to show that lower appliance prices and higher household income both increase the quantity of appliances demanded by the household:

$$
\begin{aligned}
& K_{q}\left(q, y, I^{w}\right)<0, \\
& K_{y}\left(q, y, I^{w}\right)>0,
\end{aligned}
$$

for all triples $\left(q, y, I^{w}\right)$.

The optimal choice of appliances depends on the indicator variable $I^{w}$ through two channels. First, since the household's total income inclusive of the woman's wage income is higher if $I^{w}=1$, the household chooses a higher level of $k$ when the woman works in the market. Second, if $I^{w}=1$, then the woman has less time for home production, which affects the marginal utility of an extra unit of $k$ (the right-hand side of equation 4). The second channel has an ambiguous impact on the optimal choice of $k$. On the one hand, for a given $k$, the quantity of the home good produced by the household is lower when $I^{w}=1$, increasing both the marginal utility of the home good and the demand for household capital. On the other hand, the marginal product of home capital is smaller when the woman works in the market (i.e. $I^{w}=1$ ), decreasing the incentive to purchase household capital.

We now impose further restrictions on the primitives of the model in order to obtain two additional results, which allow us to summarize GSY's argument and that facilitate the discussion of our identification strategy. We start by postulating sufficient conditions to guarantee that a household with a woman working in the market purchases more appliances than a household where the woman does not participate in the workforce, all else constant. This result is not necessary for the validity of GSY's argument, but it allows us to formalize a plausible alternative interpretation of their time-series evidence; one in which exogenous variation in female labor supply can lead to higher investment in home capital.

To state these assumptions formally, let the function $F\left(k, I^{w}\right)$ denote the right-hand side 
of equation (4):

$$
F\left(k, I^{w}\right) \equiv g^{\prime}\left(f\left(1-\bar{h} I^{w}, k\right)\right) f_{k}\left(1-\bar{h} I^{w}, k\right) .
$$

Sufficient conditions for a household with a working woman to buy more appliances than a household without a working woman $(K(q, y, 1)>K(q, y, 0))$ are: ${ }^{5}$

Assumption $1 F\left(k_{2}, I^{w}\right)<F\left(k_{1}, I^{w}\right)$ for $k_{2}>k_{1}$.

Assumption $2 F(k, 1)>F(k, 0)$ for all $k$.

We would also like to show that a married woman is more likely to participate in the workforce when the relative price of appliances $q$ declines; this result is the essence of GSY's story. Assumptions 2 and 3 guarantee that this is the case, where the latter is:

Assumption $3 k_{2} F\left(k_{2}, I^{w}\right)>k_{1} F\left(k_{1}, I^{w}\right)$ for $k_{2}>k_{1}$.

To see this result, let $V\left(I^{w}\right)$ denote the household's indirect utility function, conditional on a labor supply choice $I^{w}$ :

$$
V\left(I^{w}\right)=u\left(y+w \bar{h} I^{w}-q K\left(q, y, I^{w}\right)\right)+g\left(f\left(1-\bar{h} I^{w}, K\left(q, y, I^{w}\right)\right)\right) .
$$

The woman in the household participates in the workforce if:

$$
V(1)-V(0)-\gamma+\varepsilon>0,
$$

where, following a standard discrete-choice model, $\varepsilon$ denotes a mean-zero random variable independently distributed across households and independent of the other variables in the model. Let $G$ denote the cumulative distribution function of $\varepsilon$. The non-negative parameter

\footnotetext{
${ }^{5}$ Assumptions 1 and 2 imply that the marginal utility of an extra unit of $k$ declines as $k$ increases (assumption 1) and increases if the woman spends less time in home production (assumption 2). These two assumptions are sufficient (but not necessary) to guarantee that a household with a working woman buys more appliances because the marginal utility of market consumption is lower for such a household (due to the additional income).
} 
$\gamma$ in equation (8) captures other aggregate - possibly location and year specific - factors that might affect a married woman's labor force participation decision, over and above those already mentioned. The fraction of married women in the labor force (LFP) is then:

$$
\mathrm{LFP}=1-G(\gamma+V(0)-V(1))
$$

According to GSY, a drop in $q$ led to an increase in LFP. Showing that LFP is decreasing in $q$ amounts to showing that the sign of the following derivative is negative:

$$
\frac{\partial(V(1)-V(0))}{\partial q}=F(K(q, y, 0), 0) K(q, y, 0)-F(K(q, y, 1), 1) K(q, y, 1)
$$

The expression on the right-hand side follows from the envelope theorem and the first-order condition (4). Assumptions 2 and 3 immediately imply that the sign of this derivative is indeed negative.

In the following example, we select specific functional forms to illustrate the restrictions imposed by Assumptions 1-3.

Let:

$$
\begin{aligned}
g(x) & =\log x \\
f\left(1-\bar{h} I^{w}, k\right) & =\left[\delta(1-I \bar{h})^{\theta}+(1-\delta) k^{\theta}\right]^{\frac{1}{\theta}}, \theta \leq 1 .
\end{aligned}
$$

Then, the function $F\left(k, I^{w}\right)$ takes the following form:

$$
F\left(k, I^{w}\right)=\frac{(1-\delta) k^{\theta-1}}{\delta\left(1-\bar{h} I^{w}\right)^{\theta}+(1-\delta) k^{\theta}}
$$

Assumptions 1-3 are satisfied if $\theta>0$, i.e. if home capital and labor are gross substitutes in the home-production function. ${ }^{6}$ This interpretation of the parameter is consistent with

\footnotetext{
${ }^{6}$ The condition $(\theta>0)$ is sufficient but not necessary.
} 
GSY's view that a reduction in the relative price of home capital led to a substitution of home capital for female labor in household production.

\subsection{Discussion of the Identification Strategy}

As the model in the previous section makes clear, simply regressing the labor force participation indicator $I^{w}$ on a set of controls and the household's observed ownership of appliances using cross-sectional data will lead to inconsistent estimates. Households with relatively large $\varepsilon$ are more likely to be characterized by a working woman and will own more appliances.

Information on appliance ownership was collected in both 1960 and 1970, so we can exploit the time-series dimension of the Census data. However, the endogeneity problem remains because aggregate unobserved (to the econometrician) factors, captured by shifts in the parameter $\gamma$ in equation (9), might lead to changes in married women's labor supply

decisions, which in turn feed back into the household's choice of appliances. An example of a change in $\gamma$ which would generate this time-series pattern is the evolution of society's view of married women's role in the household.

Ideally, we would like to use exogenous cross-sectional and time-series variation in the appliance price $q$ to identify the causal effect of appliances on female labor force participation. To the best of our knowledge, detailed information on appliance prices is not available, especially for the period of interest, 1960-1970. Since we do not have disaggregated price information for our empirical analysis, we instead construct an instrument for a married woman's ownership of appliances from appliance ownership rates among single women. The optimal choice of appliances $k^{\mathrm{s}}$ by an single woman is given by:

$$
k^{\mathrm{s}}=K(q, 0,1)
$$

where the function $K$ has been defined above. We use the average observed value of $k^{\mathrm{s}}$ among single women in a given state as an instrument for ownership of appliances by a 
married woman living in that state. In selecting this instrument we think that state-year variation in the prices and operation and maintenance costs of appliances, possibly induced by differences in sales taxes, transportation costs, competition in the local durable goods market, and electricity prices, generates similar variation in appliance ownership among households with married women and households of only single women. In our model, a lower rental price $q$ leads to higher demand for appliances by both single and married women (equation 6).

Additionally, we view our instrument as unlikely to be affected by unobserved determinants of the participation decisions of married women, such as shifts in the parameter $\gamma$ in equation (8). We make this assertion because the labor force participation rates of single women remained literally constant during the 1960's, while their appliance ownership rates increased in a similar way to those of married women. ${ }^{7}$ These facts suggest that single women's labor supply around 1960 was close to its upper bound, so the diffusion of appliances did not affect their labor force participation decisions. Instead, single women purchased new home technologies when $q$ declined. Even though we cannot directly observe time-series and cross-sectional variation in $q$, we interpret the changes in appliance ownership among single women as reflecting those trends. We perform falsification and robustness exercises in Section 4 in order to evaluate the validity of our approach. The conclusion section discusses the potential drawbacks and limitations of our approach.

\section{$3 \quad$ Data and Main Results}

Next, we describe the data. Then, in Section 3.2 we introduce the benchmark regression equation and discuss the OLS estimates. Section 3.3 contains the results based on the IV approach described above.

\footnotetext{
${ }^{7}$ This point is documented in Table 2. We discuss the data further in Section 3.1. Also, the marked differences in participation trends between married and single women continued after 1970.
} 


\subsection{Data Sources and Descriptive Statistics}

We use the Integrated Public Use Microdata Series (IPUMS) from the U.S. Census of the Population for 1960, one-percent sample, and 1970, Form 1 State, one-percent sample (Ruggles et al., 2004). ${ }^{8}$ This data has several advantages. The 1960 and 1970 (Form 1) Censuses collected information on household ownership of washing machines, dryers, and freezers. ${ }^{9}$ As far as we know, the Census samples are the only large microdata set containing appliance ownership information over a period of rapid increase in the labor force participation of married women. Also, the Census samples provide demographic, employment, and income details. Unfortunately, individual observations cannot be linked across years. We focus on U.S. states because the smallest identifiable geographic region in the 1960 sample is a state. ${ }^{10}$

Our primary sample includes white, U.S.-born, married women of prime working age (1855 years old), with non-missing information on state of residence and appliance ownership, not living in group quarters and with working husbands. In the 1960 Census only 20 percent of the households in the one-percent sample were surveyed about appliance ownership, leaving 52,437 married women that satisfy our selection criteria. The 1970 sample contains 270,079 observations.

Summary statistics for married women can be found in Table 1. The labor force participation rate of married women increased from about 33 percent in 1960 to 43 percent in 1970. Labor force participation is our main outcome variable. Employment (share of married women in the labor force and holding a job), full-time employment (share of married women working at least 35 hours in the past week), and year-round employment (share of

\footnotetext{
${ }^{8}$ The Census samples can be found at http://usa.ipums.org/usa.

${ }^{9}$ The 1970 Census also asked about dishwashers, but the 1960 Census did not. For this reason we do not use the dishwasher variable in our analysis.

${ }^{10}$ The state of Hawaii is dropped from the analysis because of lack of observations for constructing the instrument in 1960. Information about a household's metropolitan area of residence is not available in the 1960 Census. In our empirical analysis we also cannot use information regarding the urban/rural location of the household or whether the household was located in a metropolitan area because, due to confidentiality concerns, this information is not available for all states in the 1960 and 1970 samples.
} 
married women working at least 48 weeks in the past year) also indicate a large increase in female labor supply during the 1960's. These alternative outcome variables are used to check the robustness of our results in Section 4.3. Notice, the average hours worked by a married woman in the labor force did not change appreciably from 1960 to 1970, suggesting that most of the observed gains in labor supply were due to change in labor force participation, our main outcome variable.

The appliance ownership dummies are the explanatory variables of interest. We recoded these appliance variables as binary indicators. For example, the WASHER variable in the Census takes on 0 (no washer), 1 (yes - automatic washer), or 2 (yes - separate spinner). We collapsed the last two categories into one category. Aggregate appliance ownership rates for freezers and dryers increased substantially for married women between 1960 and 1970. Ownership of washing machines stayed roughly constant during this period most likely because this appliance had already reached a relatively high degree of diffusion in $1960 .{ }^{11}$ The share of married women owning all three appliances increased 17 percentage points, from 10.9 percent to 27.8 percent, between 1960 and 1970.

Table 1 also summarizes the other covariates used in our analysis. Annual wage and family total incomes were adjusted for top-coding by multiplying the censored values by 1.4. We converted all dollar figures to 1970 dollars with the consumer price index (CPI All Urban Consumers series CUUR0000SA0). Household income net of female earnings is defined as family total income minus a woman's wage income. Hours worked per week and weeks worked during the previous year were imputed as the mid-points of the intervals reported by the Census.

The sample we use to construct our instruments includes white, U.S.-born, single women of prime working age (18-55 years old) who are household heads according to the Census. ${ }^{12}$

\footnotetext{
${ }^{11}$ The appliance ownership rates reported in Table 1 and Table 2 agree with those reported in GSY and Lebergott (1976).

${ }^{12}$ We use the term "single" to include both women who are single because they never married and women who were married at a previous point of their life and who are now either divorced or widows. Using only observations on women who were singles and never married gives rise to similar point estimates as the ones reported below in Table 6 , but the smaller sample size tends to increase their standard errors and reduce
} 
Table 2 reports summary statistics for single women. Unlike married women, the labor force participation rate of single women did not increase in the 1960's. However, appliance ownership rates for single women did increase in a way similar to the appliance ownership rates for married women.

Table 3 provides more detail on appliance ownership rates by year and for selected states. For both married and single women, the change in appliance ownership rates varies widely across states. As detailed in the next section, we exploit this variation in our estimation strategy.

\subsection{OLS Estimates}

The causal relationship of interest is captured by the following regression equation:

$$
\operatorname{lfp}_{i s t}=\beta \operatorname{appl}_{i s t}+x_{i s t}^{\prime} \gamma+\delta_{s}+\delta_{t}+\varepsilon_{i s t} .
$$

For each woman $i$ observed in state $s$ at time $t$, the dependent variable $\operatorname{lfp}_{\text {ist }}$ is a binary indicator for labor force participation; ${ }^{13} x_{i s t}$ is a vector of individual covariates including demographic characteristics such as education, potential experience, household income, and number of children; $\delta_{s}$ and $\delta_{t}$ represent state-of-residence and Census year main effects, respectively; $\varepsilon_{i s t}$ is a disturbance term; and the dummy variable appl $l_{i s t}$ captures the presence of household appliances. The variable appl ${ }_{i s t}$ is the key regressor of interest. We experiment with three alternative specifications for this regressor. First, we include one appliance dummy at a time in equation (10). Second, we simultaneously include all three appliance dummies (washing machines, dryers, and freezers). Third, we use a single dummy that takes a value of 1 if the household owns all three appliances and zero otherwise. Each of these alternative versions of the independent variable represents an imperfect empirical counterpart for the variable $k$ in the model of Section 2.1 because the Census data only contains information

\footnotetext{
${ }^{13}$ In Section 4.3 we provide results using alternative measures of labor supply.
} 
about a limited set of home durable goods. Our preferred specification is the one that employs the binary indicator of ownership of all three appliances. This variable conveniently summarizes the information on appliance ownership by implicitly assigning the same degree of importance to each appliance for which information is available.

Table 4, columns 1-5, reports the OLS estimates of the parameter $\beta$ in equation (10). Labor force participation for married women has a negative correlation with the ownership of washers and freezers and a positive association with the ownership of dryers. The signs of these correlations are the same whether all three appliance regressors are included in the regression equation at the same time or separately. Ownership of all three appliances is positively associated with female labor force participation, but the relationship is statistically insignificant in the OLS case. Estimates of the marginal effects implied by a probit model (reported in Table 4, column 6) are slightly larger than the OLS results, but still borderline significant. Taken together, the estimates in Table 4 do not lend much support to GSY's hypothesis. The estimated magnitude of $\beta$ is relatively small and sometimes of the wrong sign.

As argued in Section 2, caution must be exercised in interpreting the OLS results because the appliance regressor is likely to be endogenous. At least three potential sources of bias exist. First, households with a working woman are more likely to purchase appliances. Reverse causation could induce a positive bias in the estimate of $\beta$. Second, households with strong tastes for home-produced goods might invest heavily in both inputs of home production, namely household work (traditionally carried out by the wife) and household appliances. These unobserved preference shifters (which cannot be fully captured by the covariates) may induce a negative correlation between appliance ownership and female labor participation, creating a downward bias in the OLS estimate of $\beta$. Third, in the presence of measurement error in $\operatorname{appl}_{i s t}$ the OLS estimator of its coefficient will be attenuated toward zero, as is well known. Given these potential sources of bias, we turn to an IV approach. 


\subsection{Estimation and Main Results}

To consistently estimate the parameter $\beta$ in equation (10) we need a variable that is correlated with appl $l_{i s t}$ but not with the error term $\varepsilon_{i s t}$. As mentioned in Section 2 we instrument the endogenous regressor appl ${ }_{i s t}$ with the state-year mean appliance ownership rate among single women, denoted by appl-sin $n_{s t}$. Table 5 displays estimates of the first-stage regression models: ${ }^{14}$

$$
\operatorname{appl}_{i s t}=\pi \operatorname{appl}_{-\sin _{s t}}+x_{i s t}^{\prime} \varphi+\lambda_{s}+\lambda_{t}+u_{i s t} .
$$

In all specifications, we find a sizable, positive, and statistically significant relationship between appl $\mathrm{ast}_{\text {ist }}$ and its corresponding instrumental variable appl-sin ${ }_{s t}$. For example, the entry in the first column of Table 5 indicates that a 10 percentage point increase in ownership of washers among single women is associated with a 2.45 percentage point increase in the fraction of married women owning washers. The F-statistics for the significance of the estimated coefficients on the instruments are 13 or higher in all cases; this strong first-stage dispels any concerns about serious finite-sample bias problems in the IV estimates (Bound, Jaeger, and Baker, 1995).

The two-stage least-squares (2SLS) estimates of equation (10) represent our main results (see Table 6). The findings are generally consistent with the existence of a positive statistically and economically significant causal effect of appliance ownership on female labor force participation of married women. For example, the 2SLS estimate reported in Table 6 , column 5 (our preferred specification) implies that owning all three appliances raises the likelihood of labor force participation by married women by about 26 percentage points, with a standard error of 5.8 percentage points.

The share of married women owning all three appliances increased by 17 percentage points from 1960 to 1970 (see Table 1). Therefore, our results suggest that higher ownership of appliances accounts for a 4.42 percentage point $(0.26 \times 0.17)$ increase in the labor force

\footnotetext{
${ }^{14}$ Recall that when all three appliances are included in the regression at the same time, $\pi$ is a threedimensional vector.
} 
participation rate of married women during the 1960's. The labor force participation rate of married women increased by 10 percentage points during this decade. The other estimates in Table 6 confirm this baseline result. Using only the variable "freezer" as a measure of appliance ownership produces a similar result to the baseline. Using the variable "dryer", either on its own or together with the other two (columns 3 and 4), suggests a larger effect. ${ }^{15}$

The 2SLS approach generates uniformly larger estimates for the parameter $\beta$ (see Table 6) than the OLS estimates of Table 4. This discrepancy does not seem to be due to a reverse causation argument (i.e. higher labor force participation of married women leading to higher appliance ownership), which would have led to the opposite ranking of these estimates. As described above, these results are consistent with attenuation bias due to measurement error in the endogenous regressor $\operatorname{appl}_{i s t}$ and with negative bias because of unobservable tastes for home-produced goods causing both high appliance ownership and low female participation rates.

\section{Alternative Specifications and Robustness Checks}

In this section, we describe the results from robustness checks and falsification exercises. The purpose is to show the consistency of the findings reported in Table 6 and to provide support for our IV strategy.

\subsection{Falsification Exercises}

This section presents two falsification exercises. The first exercise checks whether our instrument $\left(\operatorname{appl}_{-\mathrm{sin}_{s t}}\right)$ also predicts changes in participation of single women. The concern is that unobservable state-year specific shocks might lead to higher labor force participation by both married and single women, leading both married and single women to purchase

\footnotetext{
${ }^{15}$ Notice that, while the estimated coefficient on the variable "washer" is positive (column 1 in Table 6), there has not been an increase in ownership of that appliance among married women in the 1960's.
} 
more appliances. ${ }^{16}$ In this case our instrument would be correlated with the residual in equation (10) violating the fundamental condition for its validity. Table 7 , columns $1-5$, displays the 2SLS estimates of the parameter $\beta$ in the regression (10) obtained using data on single women only. The instrument for single women appliance ownership is built using appl-sin $\sin _{s t}$, as before. The estimate of $\beta$ is not statistically significant in any of the different specifications of this regression, supporting the assertion that reverse causation is unlikely to account for our findings.

Admittedly, this falsification exercise only rules out interpretations of our results based on unobserved state and year specific shocks that cause women - both single and married to join the workforce and, through this channel, decide to purchase more appliances. ${ }^{17}$ The falsification exercise does not address situations in which unobserved state and year specific shocks have a positive independent effect on both a woman's incentive to join the labor force and on her decision to own appliances. In this case, the fact that single women's labor force participation did not increase jointly with their ownership of appliances could simply reflect the fact that in 1960 their rates of participation were already relatively high. We cannot rule out the existence of shocks that have an independent effect on each of these two margins; however, it is difficult to think of an example capable of explaining the contemporaneous rise in married women's labor force participation and their ownership of appliances. ${ }^{18}$

The second falsification exercise checks whether including a non-productive appliance, a television, to our set of endogenous regressors generates additional predictive power. The existence of such an effect induced by a non-productive appliance would diminish the plau-

\footnotetext{
${ }^{16}$ These shocks can be interpreted as shifts in the parameter $\gamma$ in equation (9).

${ }^{17}$ Recall that, everything else equal, appliance ownership is higher for employed relative to non-employed women in the model of Section 2.1.

${ }^{18}$ A candidate shock would be a change in preferences for the home-produced good. Preferences directly affect both a household's decision to purchase appliances and a married woman's decision to participate in the labor force. However, this kind of shock cannot rationalize the simultaneous increase in appliance ownership and female labor supply observed in the data. A lower weight on home goods in the utility function increases women's labor force participation but decreases their willingness to own consumer durables. An increase in appliance ownership by married women might occur but it would be the result of increased participation, instead of a direct implication of the underlying shock. Our falsification exercise already rules out this possibility.
} 
sibility of interpreting our main results as evidence of a causal link between ownership of home appliances and married women's labor force participation. Table 7, columns 6-10, presents the 2SLS estimates from this exercise; ownership of a television at the household level is instrumented, as above, by the state-year specific ownership rate by single women. Television ownership is not significantly associated with the dependent variable in any of the different versions of our regression equation, after including one of the original productive appliances in the specification of the regression.

Ownership of a television set does have a positive and statistically significant effect on female labor force participation when it is the only endogenous regressor in equation (10) (see Table 7, column 10). We do not believe this result falsifies our IV strategy because if productive appliances do indeed have an effect on female labor force participation, then a model based solely on a non-productive appliance would be misspecified. Leaving out the original regressor(s) artificially creates an omitted variable problem, as state level ownership rates of different appliances are likely correlated among themselves. ${ }^{19}$ Thus, adding the non-productive appliance to the existing endogenous regressor(s) in equation (10) is the relevant test. We conclude this section by noting that neither of the two falsification exercises invalidates our IV approach.

\subsection{Changing School Enrollment and Other Robustness Checks}

In 1960, the female college enrollment rate among 16-24 year-olds was 37.9 percent. A decade later, this statistic had increased to 48.5 percent. The increase in schooling could pose a problem for our identification strategy. Differential trends in school enrollment rates can mechanically affect labor force participation rates (through an "incapacitation effect") and make the use of single women as an instrument potentially problematic. To address this concern, we re-estimate our main regressions excluding college-age women. The first column of Table 8 reports estimates from OLS and 2SLS models with the sample restricted

\footnotetext{
${ }^{19}$ The partial correlation coefficient between ownership of a television and ownership of other appliances is positive and statistically significant even after controlling for the covariates in our regression specifications.
} 
to 24-55 year-olds. In order to limit the number of tables, in Tables 8 and 9 we focus on the results of our preferred specification in which the endogenous regressor is the indicator variable "ownership of all three appliances". The estimated coefficient $\beta$ is slightly smaller when the sample is restricted to $24-55$ years-olds, but the magnitude of the results is largely unchanged relative to the benchmark specification.

Differential selection into the labor force due to changing college enrollment could also undermine our first falsification exercise. In particular, if the single young women in our sample are more likely to be full-time students in 1970 than a decade earlier, we would expect this "incapacitation effect" to have mechanically reduced the observed labor force participation of single women in 1970. A reduction in labor force participation by single women attending college could have masked any increases in the participation of non-collegegoing single women between 1960 and 1970. Our estimates in Table 8 would be biased downwards, rendering our first falsification exercise uninformative. However, excluding 1823 year-olds does not change the results of the falsification exercise. The 2SLS estimate of $\beta$ when the labor force participation of single women is used as the dependent variable is 0.06 with a standard error of 0.12 , further reinforcing our conclusion that reverse causality cannot explain our main results. ${ }^{20}$

Table 8 also contains the results of three further robustness checks. First, we use single men together with single women to construct the instrument for the endogenous regressor "ownership of all three appliances". Second, we use single women in the labor force to construct the instrument for the endogenous regressor "ownership of all three appliances". Third, we include in our benchmark regression a measure of the gender wage gap, as emphasized by Jones, Manuelli, and McGrattan (2003). The measure of the wage gap we use is the ratio between state-level average wages of female and men full-time full-year workers. In these three cases, reported respectively in Table 8, columns 2-4, the 2SLS estimates of

\footnotetext{
${ }^{20}$ These estimates are not reported in Table 8. Differently from college enrollment rates, marriage rates were not very different in 1960 and 1970. In a previous version of the paper we controlled for potential selection effects related to marriage by using Hunt (2002)'s selection correction procedure. We found that this procedure had negligible effects on our results.
} 
the coefficient $\beta$ remain between 0.25 and 0.27 and highly statistically and economically significant, confirming our previous results.

\subsection{Alternative Outcome Variables}

Until now we have focused on female labor force participation as the outcome variable of interest; next, we evaluate the effect of appliance ownership on alternative measures of labor supply. We have estimated four additional versions of the basic model. The dependent variable is either a woman's employment status (1 if employed, 0 otherwise), or whether she is working full-time ( 1 if working $35+$ hours per week), or whether she is working yearround ( 1 if working $48+$ weeks per year). We also use total hours worked by a married woman in the year prior to the Census (with a value of 0 if she did not work in the market) as a dependent variable. OLS and 2SLS results are reported in Table 9. In all the 2SLS specifications, appliance ownership has a positive and statistically significant impact on female labor supply. The increase in appliance ownership accounts for about 40 percent of the observed increase in the employment rate among married women in the 1960's and for about 54 percent of the increase in the share of married women who work year-round. The results for the dummy "work full-time" indicates even larger effects. Finally, the diffusion of appliances is associated with an average (per married woman) increase of 92 hours worked per year. This is about 71 percent of the observed increase in average hours by married women (including women who did not work in the market) that took place between 1960 and 1970. Taken together these results confirm the findings of the baseline model in Table 6.

\section{Conclusions}

We use microdata from the U.S. Census to evaluate the contribution of household appliances to the increase in female labor force participation during the 1960's. According to 
our estimates, household appliances account for about forty percent of the actual increase in participation by married women during this period of time.

The key to our approach is the observation that single women's labor supply did not increase during the 1960's. We therefore use single women's ownership of an appliance in a given state as an instrument for a married woman's ownership of that appliance. An implicit assumption that underscores our identification strategy is that the relative price of appliances, $q$, in a given state is independent of married women's labor supply decisions. If this were not the case, independent shifts in married women's labor supply might lead to changes in $q$ and affect the appliance purchasing decisions of singles as well. We cannot rule this channel out. However, for this argument to account for the patterns of participation and appliance ownership observed in the data, it would have to be the case that the higher demand for appliances by married women who recently joined the workforce drove down appliance prices, to induce an increase in adoption by singles. If appliance prices went up in states with higher demand, as standard demand/supply models would suggest, the quantity of appliances demanded by singles would decline. This pattern would be inconsistent with the data. Of course, we cannot rule out the possibility that increasing returns to scale in the shipping and delivery of these capital goods, or the dependence of price mark-ups on the size of the local market, could generate downward sloping supply curves for appliances. More generally, a similar criticism could be addressed at the GSY's story altogether. The observed negative time-series association between female labor supply and the relative price of home appliances that GSY emphasize might be driven by changes in participation by married women, rather than by prices.

Absent data on appliance prices, alternative approaches to identification in this area might rely on cross-sectional and time-series variation in variables that are associated with the cost of operating an appliance unit, e.g. electricity prices. State-level data on electricity prices is available for 1960 and 1970, but unfortunately during this decade the cost of electricity has changed proportionately across states, limiting the extent of variation that might 
be usefully exploited in a first-stage regression. ${ }^{21}$ While the electrification of the U.S. was largely completed by 1960 (see Bailey and Collins, 2006), the current experience of some developing countries can provide a more data-rich testing ground for GSY's theory, as exemplified by Dinkelman (2008)'s work cited in the introduction. Her results are qualitatively consistent with ours, despite referring to a different country and a different time period.

In conclusion, we do not regard changes in home durable goods prices to be the only or even the most important driver of female labor supply in recent U.S. history. Our results imply that more than half of the increase in the labor supply of married women during the 1960's is due to factors different than the diffusion of home appliances. However, our results do point to technological progress as a potentially important factor in economic and social change. Recent research by Greenwood and Guner (2008) argues that technological progress in the household sector can also help to explain the increase in the divorce rate and the decline in the rate of marriage in the U.S. after WWII. Our findings confirm that this represents a fruitful area to be further explored in future research.

\footnotetext{
${ }^{21}$ Notice that the assumption of exogeneity of electricity prices relative to married women's labor supply would have to be entertained also in this case in order to justify the validity of this instrument.
} 


\section{References}

Aguiar, M., and E. Hurst (2006): "Measuring Trends in Leisure: The Allocation of Time Over Five Decades," Federal Reserve Bank of Boston, Working Paper(06/2).

Albanesi, S., And C. Olivetti (2007): "Gender Roles and Technological Progress," NBER Working Paper 13179.

Bailey, M. J., And W. J. Collins (2006): "The Demographic Effects of Household Electrification in the United States, 1925 to 1960," Working Paper.

Becker, G. S. (1965): "A Theory of the Allocation of Time," Economic Journal, 75(3), 493-517.

Bianchi, S. M., M. A. Milkie, L. C. Sayer, and J. Robinson (2000): "Is Anyone Doing the Housework? Trends in the Gender Division of Household Labor," Social Forces, 79(1), 191-228.

Bittman, M., J. Rice, and J. Wajcman (2004): "Appliances and Their Impact: The Ownership of Domestic Technology and Time Spent on Household Work," The British Journal of Sociology, 55, 401-423.

Bound, J., A. Jaeger, And R. BAKer (1995): "Problems with Instrumental Variables Estimation When the Correlation Between the Instruments and Endogenous Explanatory Variables is Weak," Journal of the American Statistical Association, 90, 443-450.

Cardia, E. (2008): "Household Technology: Was It the Engine of Liberation," Universite de Montreal and CIREQ Working Paper. 
Cavalcanti, T., and J. Tavares (2008): "Assessing the "Engines of Liberation": Home Appliances and Female Labor Force Participation," Review of Economics and Statistics, $90(1), 81-88$.

Cortes, P., and J. Tessada (2007): "Cheap Maids and Nannies: How Low-Skilled Immigration is Changing the Labor Supply of High-Skilled American Women," Working Paper Chicago GSB.

Cowan, R. S. (1983): More Work for Mother: The Ironies of Household Technology from the Open Hearth to the Microwave. Basic Books, New York.

Dinkelman, T. (2008): "The Effects of Rural Electrification on Employment: New Evidence from South Africa," University of Michigan Working Paper.

Evans, W., And J. Angrist (1998): "Children and Their Parents' Labor Supply: Evidence from Exogenous Variation in Family Size," American Economic Review, 88, 450-477.

Fernandez, R., A. Fogli, and C. Olivetti (2004): "Mothers and Sons: Preference Formation and Female Labor Force Dynamics," The Quarterly Journal of Economics, $119,1249-1299$.

Gayle, G.-L., and L. Golan (2006): "Estimating a Dynamic Adverse-Selection Model: Labor Force Experience and the Changing Gender Earnings Gap 1968-93," Working Paper.

Goldin, C. (1990): Understanding the Gender Gap, NBER Series on Long-Term Factors in Economic Development. Oxford University Press, New York.

Goldin, C., And L. F. Katz (2002): "The Power of the Pill: Oral Contraceptives and Women's Career and Marriage Decisions," Journal of Political Economy, 110(4), 730-770. 
Greenwood, J., And N. Guner (2008): "Marriage and Divorce Since World War II: Analyzing the Role of Technological Progress on the Formation of Households," NBER Macroeconomics Annual, 23.

Greenwood, J., A. Seshadri, and M. Yorukoglu (2005): "Engines of Liberation," Review of Economic Studies, 72, 109-133.

Gronau, R. (1977): "Leisure, Home Production and Work - The Theory of the Allocation of Time Revisited," Journal of Political Economy, 85(4), 1099-1123.

Hunt, J. (2002): "The Transition in East Germany: When is a Ten Point Fall in the Gender Wage Gap Bad News?," Journal of Labor Economics, 20, 148-169.

Jones, L. E., R. E. Manuelli, and E. R. McGrattan (2003): "Why Are Married Women Working So Much?," Federal Reserve Bank of Minneapolis Research Department Staff Report $31 \%$.

Lebergott, S. (1976): The American Economy: Income, Wealth, and Want. Princeton University Press, Princeton, NJ.

Roberts, K., and P. Rupert (1995): "The Myth of the Overworked American," Economic Commentary, Federal Reserve Bank of Cleveland.

Ruggles, S., M. Sobek, T. Alexander, C. A. Fitch, R. Goeken, P. K. Hall, M. King, and C. Ronnander (2004): "Integrated Public Use Microdata Series: Version 3.0 [Machine-Readable Database]," Minnesota Population Center.

Smith, J. P., And M. P. Ward (1985): "Time-Series Growth in the Female Labor Force," Journal of Labor Economics, 3(1), 59-90.

Wong, L. Y. (2008): "Women's Economic Progress and Technological Change," Working Paper. 
Table 1: Summary Statistics for Married Women Aged 18-55

Variables

All

1970

Outcome Variables

Participation Rate

0.410

0.327

0.427

(0.492)

$(0.469)$

(0.495)

Employment Rate

0.391

0.311

0.407

(0.488)

(0.463)

$(0.491)$

Share Working Full-Time

0.253

0.214

0.261

(0.435)

$(0.410)$

(0.439)

Share at Work Year-Round

0.238

0.181

0.250

(48+ Weeks in Prior Year)

(0.426)

(0.385)

(0.433)

Hours Worked per Week

34.1

34.9

34.0

(10.5)

(10.6)

(10.5)

Endogenous Regressors of Interest

Washer Present 0.854

(0.353)

0.871

(0.335)

0.851

in the Household

0.565

0.293

(0.356)

Dryer Present

(0.496)

(0.455)

0.618

in the Household

0.351

0.254

(0.486)

Freezer Present

(0.477)

(0.435)

0.370

in the Household

0.251

0.109

(0.312)

(0.483)

All 3 Appliances Present

(0.433)

Covariates

Age

36.8

36.9

36.8

(10.2)

(9.7)

(10.3)

Number of Children Under

0.44

0.55

0.41

Age 5

(0.73)

(0.84)

(0.70)

Number of Children Over

1.43

1.31

1.45

Age 5

(1.48)

(1.35)

(1.51)

Potential Experience

19.1

(10.7)

19.7

19.0

(Years)

(10.2)

(10.8) 
Table 1 (continued): Summary Statistics for Married Women Aged 18-55

\begin{tabular}{lccc} 
Variables & All & 1960 & 1970 \\
\hline & & & \\
Share with 0-11 & 0.324 & 0.432 & 0.303 \\
Years of Schooling & $(0.468)$ & $(0.495)$ & $(0.460)$ \\
Share with 12 & 0.467 & 0.398 & 0.480 \\
Years of Schooling & $(0.499)$ & $(0.489)$ & $(0.500)$ \\
Share with 13-15 & 0.124 & 0.109 & 0.127 \\
Years of Schooling & $(0.329)$ & $(0.312)$ & $(0.333)$ \\
& 0.085 & 0.061 & 0.090 \\
$\begin{array}{l}\text { Share with 16 or More } \\
\text { Years of Schooling }\end{array}$ & $(0.279)$ & $(0.239)$ & $(0.286)$ \\
& & & \\
$\begin{array}{l}\text { Household Income } \\
\text { (minus own earnings) }\end{array}$ & 10,706 & 8,674 & 11,100 \\
& $(8,050)$ & $(6,459)$ & $(8,266)$
\end{tabular}

\section{Instruments}

$\begin{array}{lccc}\text { Share of Single Women in } & 0.581 & 0.586 & 0.580 \\ \text { State Owning a Washer } & (0.077) & (0.102) & (0.071) \\ & & & \\ \text { Share of Single Women in } & 0.285 & 0.100 & 0.321 \\ \text { State Owning a Dryer } & (0.115) & (0.070) & (0.084) \\ & & & \\ \text { Share of Single Women in } & 0.147 & 0.084 & 0.159 \\ \text { State Owning a Freezer } & (0.062) & (0.041) & (0.057) \\ & & & 0.095 \\ \text { Share of Single Women in } & 0.084 & 0.026 & (0.038) \\ \begin{array}{l}\text { State Owning All Three } \\ \text { Appliances }\end{array} & (0.044) & (0.025) & \\ & & & \\ & & & \\ \text { Number of Observations } & 322,516 & 52,437 & 270,079\end{array}$

Notes: Entries are means with standard deviations reported in parentheses. The data are from the Census IPUMS for 1960 and 1970 (State Form 1), with the sample restricted to white, U.S.-born, married women of prime working age (18 to 55 years old), with state information, and working husbands. Dollar amounts are in 1970 dollars. 
Table 2: Summary Statistics for Single Women Aged 18-55

\begin{tabular}{|c|c|c|c|}
\hline Variables & All & 1960 & 1970 \\
\hline & \multicolumn{3}{|c|}{ Outcome Variables } \\
\hline Participation Rate & $\begin{array}{c}0.785 \\
(0.411)\end{array}$ & $\begin{array}{c}0.781 \\
(0.414)\end{array}$ & $\begin{array}{c}0.785 \\
(0.410)\end{array}$ \\
\hline Employment Rate & $\begin{array}{c}0.756 \\
(0.423)\end{array}$ & $\begin{array}{c}0.746 \\
(0.435)\end{array}$ & $\begin{array}{c}0.757 \\
(0.428)\end{array}$ \\
\hline $\begin{array}{l}\text { Share Working Full-Time } \\
\text { (35+ Hours/Week) }\end{array}$ & $\begin{array}{c}0.606 \\
(0.489)\end{array}$ & $\begin{array}{c}0.626 \\
(0.484)\end{array}$ & $\begin{array}{c}0.603 \\
(0.489)\end{array}$ \\
\hline $\begin{array}{l}\text { Share at Work Year-Round } \\
(48+\text { Weeks in Prior Year) }\end{array}$ & $\begin{array}{c}0.556 \\
(0.497)\end{array}$ & $\begin{array}{c}0.539 \\
(0.498)\end{array}$ & $\begin{array}{c}0.559 \\
(0.496)\end{array}$ \\
\hline \multirow[t]{2}{*}{$\begin{array}{l}\text { Hours Worked per Week } \\
\text { (Conditional on Working) }\end{array}$} & $\begin{array}{l}37.7 \\
(7.8)\end{array}$ & $\begin{array}{l}38.2 \\
(7.6)\end{array}$ & $\begin{array}{l}37.6 \\
(7.8)\end{array}$ \\
\hline & \multicolumn{3}{|c|}{ Endogenous Regressors of Interest } \\
\hline $\begin{array}{l}\text { Washer Present } \\
\text { in the Household }\end{array}$ & $\begin{array}{c}0.572 \\
(0.495)\end{array}$ & $\begin{array}{c}0.576 \\
(0.494)\end{array}$ & $\begin{array}{c}0.572 \\
(0.495)\end{array}$ \\
\hline $\begin{array}{l}\text { Dryer Present } \\
\text { in the Household }\end{array}$ & $\begin{array}{c}0.291 \\
(0.454)\end{array}$ & $\begin{array}{c}0.100 \\
(0.300)\end{array}$ & $\begin{array}{c}0.317 \\
(0.465)\end{array}$ \\
\hline $\begin{array}{l}\text { Freezer Present } \\
\text { in the Household }\end{array}$ & $\begin{array}{c}0.143 \\
(0.350)\end{array}$ & $\begin{array}{c}0.080 \\
(0.272)\end{array}$ & $\begin{array}{c}0.152 \\
(0.359)\end{array}$ \\
\hline $\begin{array}{l}\text { All } 3 \text { Appliances Present } \\
\text { in the Household }\end{array}$ & $\begin{array}{c}0.084 \\
(0.278)\end{array}$ & $\begin{array}{l}0.0256 \\
(0.158)\end{array}$ & $\begin{array}{c}0.092 \\
(0.289)\end{array}$ \\
\hline
\end{tabular}


Table 2 (continued): Summary Statistics for Single Women Aged 18-55

\begin{tabular}{|c|c|c|c|}
\hline Variables & All & 1960 & 1970 \\
\hline & \multicolumn{3}{|c|}{ Covariates } \\
\hline Age & $\begin{array}{c}39.5 \\
(11.0)\end{array}$ & $\begin{array}{l}41.9 \\
(9.8)\end{array}$ & $\begin{array}{c}39.2 \\
(11.1)\end{array}$ \\
\hline $\begin{array}{l}\text { Number of Children Under } \\
\text { Age } 5\end{array}$ & $\begin{array}{c}0.14 \\
(0.45)\end{array}$ & $\begin{array}{c}0.12 \\
(0.44)\end{array}$ & $\begin{array}{c}0.14 \\
(0.45)\end{array}$ \\
\hline $\begin{array}{l}\text { Number of Children Over } \\
\text { Age } 5\end{array}$ & $\begin{array}{c}0.95 \\
(1.35)\end{array}$ & $\begin{array}{c}0.84 \\
(1.21)\end{array}$ & $\begin{array}{c}0.97 \\
(1.37)\end{array}$ \\
\hline $\begin{array}{l}\text { Potential Experience } \\
\text { (Years) }\end{array}$ & $\begin{array}{c}21.7 \\
(11.8)\end{array}$ & $\begin{array}{c}24.7 \\
(10.5)\end{array}$ & $\begin{array}{l}21.3 \\
(12.0)\end{array}$ \\
\hline $\begin{array}{l}\text { Share with } 0-11 \\
\text { Years of Schooling }\end{array}$ & $\begin{array}{c}0.355 \\
(0.479)\end{array}$ & $\begin{array}{c}0.469 \\
(0.499)\end{array}$ & $\begin{array}{c}0.340 \\
(0.474)\end{array}$ \\
\hline $\begin{array}{l}\text { Share with } 12 \\
\text { Years of Schooling }\end{array}$ & $\begin{array}{c}0.372 \\
(0.483)\end{array}$ & $\begin{array}{c}0.309 \\
(0.462)\end{array}$ & $\begin{array}{c}0.381 \\
(0.486)\end{array}$ \\
\hline $\begin{array}{l}\text { Share with 13-15 } \\
\text { Years of Schooling }\end{array}$ & $\begin{array}{c}0.143 \\
(0.350)\end{array}$ & $\begin{array}{c}0.116 \\
(0.320)\end{array}$ & $\begin{array}{c}0.147 \\
(0.354)\end{array}$ \\
\hline $\begin{array}{l}\text { Share with } 16 \text { or More } \\
\text { Years of Schooling }\end{array}$ & $\begin{array}{c}0.129 \\
(0.335)\end{array}$ & $\begin{array}{c}0.106 \\
(0.308)\end{array}$ & $\begin{array}{c}0.132 \\
(0.339)\end{array}$ \\
\hline $\begin{array}{l}\text { Household Income } \\
\text { (minus own earnings) }\end{array}$ & $\begin{array}{c}1,977 \\
(3,732)\end{array}$ & $\begin{array}{c}1,926 \\
(3,686)\end{array}$ & $\begin{array}{c}1,984 \\
(3,738)\end{array}$ \\
\hline Number of Observations & 43,984 & 5,267 & 38,717 \\
\hline
\end{tabular}

Notes: Entries are means with standard deviations reported in parentheses. The data are from the Census IPUMS for 1960 and 1970 (State Form 1), with the sample restricted to white, U.S.-born, single women of prime working age (18 to 55 years old) who are household heads, and with state information. Dollar amounts are in 1970 dollars. 
Table 3: Mean State Appliance Ownership Rates by Demographic Group, 1960-1970 Married Women Aged 18-55 Single Women Aged 18-55

\begin{tabular}{|c|c|c|c|c|}
\hline Variables & 1960 & 1970 & 1960 & 1970 \\
\hline \multicolumn{5}{|c|}{ Percent with Clothes Washer in Household: } \\
\hline Overall Average & $\begin{array}{c}0.873 \\
(0.069)\end{array}$ & $\begin{array}{c}0.853 \\
(0.052)\end{array}$ & $\begin{array}{c}0.585 \\
(0.153)\end{array}$ & $\begin{array}{c}0.589 \\
(0.088)\end{array}$ \\
\hline Lowest State Average & $\begin{array}{l}0.594 \\
{[\mathrm{DC}]}\end{array}$ & $\begin{array}{l}0.593 \\
{[\mathrm{DC}]}\end{array}$ & $\begin{array}{l}0.000 \\
{[\mathrm{AL}]}\end{array}$ & $\begin{array}{l}0.279 \\
{[\mathrm{DC}]}\end{array}$ \\
\hline Highest State Average & $\begin{array}{l}0.981 \\
{[\mathrm{VT}]}\end{array}$ & $\begin{array}{l}0.919 \\
{[\mathrm{LA}]}\end{array}$ & $\begin{array}{l}0.867 \\
{[\mathrm{WV}]}\end{array}$ & $\begin{array}{l}0.708 \\
{[\mathrm{WY}]}\end{array}$ \\
\hline \multicolumn{5}{|c|}{ Percent with Clothes Dryer in Household: } \\
\hline Overall Average & $\begin{array}{c}0.272 \\
(0.132)\end{array}$ & $\begin{array}{c}0.607 \\
(0.116)\end{array}$ & $\begin{array}{c}0.091 \\
(0.086)\end{array}$ & $\begin{array}{c}0.319 \\
(0.087)\end{array}$ \\
\hline Lowest State Average & $\begin{array}{l}0.069 \\
{[\mathrm{AZ}]}\end{array}$ & $\begin{array}{l}0.376 \\
{[\mathrm{AZ}]}\end{array}$ & $\begin{array}{c}0.000 \\
{[\mathrm{AK}, \mathrm{VT}, \mathrm{AL}, \mathrm{NV}} \\
\text { SD, ME] }\end{array}$ & $\begin{array}{l}0.185 \\
{[\mathrm{NV}]}\end{array}$ \\
\hline Highest State Average & $\begin{array}{l}0.559 \\
{[\mathrm{OR}]}\end{array}$ & $\begin{array}{l}0.805 \\
\text { [WA] }\end{array}$ & $\begin{array}{l}0.444 \\
{[\mathrm{ND}]}\end{array}$ & $\begin{array}{l}0.488 \\
{[\mathrm{OR}]}\end{array}$ \\
\hline \multicolumn{5}{|c|}{ Percent with Freezer in Household: } \\
\hline Overall Average & $\begin{array}{c}0.288 \\
(0.101)\end{array}$ & $\begin{array}{c}0.413 \\
(0.122)\end{array}$ & $\begin{array}{c}0.087 \\
(0.061)\end{array}$ & $\begin{array}{c}0.183 \\
(0.073)\end{array}$ \\
\hline Lowest State Average & $\begin{array}{l}0.095 \\
\text { [MA] }\end{array}$ & $\begin{array}{c}0.162 \\
{[\mathrm{RI}]}\end{array}$ & $\begin{array}{c}0.000 \\
\text { [DC, VT, RI, NV, } \\
\text { DE, WY, AL] }\end{array}$ & $\begin{array}{l}0.039 \\
{[\mathrm{DC}]}\end{array}$ \\
\hline Highest State Average & $\begin{array}{l}0.562 \\
{[\mathrm{ND}]}\end{array}$ & $\begin{array}{l}0.675 \\
{[\mathrm{ND}]}\end{array}$ & $\begin{array}{l}0.225 \\
{[\mathrm{OR}]}\end{array}$ & $\begin{array}{l}0.397 \\
{[\mathrm{MS}]}\end{array}$ \\
\hline \multicolumn{5}{|c|}{ Percent with All 3 Appliances in Household: } \\
\hline Overall Average & $\begin{array}{c}0.114 \\
(0.072)\end{array}$ & $\begin{array}{c}0.304 \\
(0.114)\end{array}$ & $\begin{array}{c}0.026 \\
(0.037)\end{array}$ & $\begin{array}{c}0.108 \\
(0.054)\end{array}$ \\
\hline Lowest State Average & $\begin{array}{l}0.031 \\
{[\mathrm{AZ}]}\end{array}$ & $\begin{array}{c}0.118 \\
{[\mathrm{RI}]}\end{array}$ & $\begin{array}{c}0.000 \\
\text { [AL, AK, DC, DE, } \\
\text { FL, KS, LA, MA, } \\
\text { ME, NC, NH, NJ, } \\
\text { NV, OK, RI, SC, } \\
\text { SD, VT, WY] }\end{array}$ & $\begin{array}{l}0.013 \\
{[\mathrm{DC}]}\end{array}$ \\
\hline Highest State Average & $\begin{array}{l}0.300 \\
{[\mathrm{OR}]}\end{array}$ & $\begin{array}{l}0.571 \\
{[\mathrm{ND}]}\end{array}$ & $\begin{array}{l}0.222 \\
{[\mathrm{ND}]}\end{array}$ & $\begin{array}{l}0.250 \\
{[\mathrm{ND}]}\end{array}$ \\
\hline Number of Observations & 50 & 50 & 50 & 50 \\
\hline
\end{tabular}

Notes: Entries are means with standard deviations reported in parentheses. See notes to Tables 1 and 2. 
Table 4: OLS and Probit Estimates of the Effect of Household Appliances on the Labor Force Participation of Married Women

\begin{tabular}{|c|c|c|c|c|c|c|}
\hline & $\begin{array}{r}\text { OLS } \\
(1) \\
\end{array}$ & $\begin{array}{l}\text { OLS } \\
(2)\end{array}$ & $\begin{array}{l}\text { OLS } \\
(3)\end{array}$ & $\begin{array}{r}\text { OLS } \\
(4) \\
\end{array}$ & $\begin{array}{l}\text { OLS } \\
(5)\end{array}$ & $\begin{array}{c}\text { Probit } \\
(6)\end{array}$ \\
\hline Washer Present in the Household & $\begin{array}{c}-0.055^{* * *} \\
(0.003)\end{array}$ & & & $\begin{array}{l}-0.068^{* * *} \\
(0.003)\end{array}$ & & \\
\hline Dryer Present in the Household & & $\begin{array}{r}0.003 \\
(0.003)\end{array}$ & & $\begin{array}{l}0.025^{* * *} \\
(0.003)\end{array}$ & & \\
\hline Freezer Present in the Household & & & $\begin{array}{l}-0.005 \\
(0.003)\end{array}$ & $\begin{array}{c}-0.002 \\
(0.003)\end{array}$ & & \\
\hline $\begin{array}{l}\text { All Three Appliances Present in the } \\
\text { Household }\end{array}$ & & & & & $\begin{array}{c}0.003 \\
(0.002)\end{array}$ & $\begin{array}{r}0.010^{*} \\
(0.006)\end{array}$ \\
\hline
\end{tabular}

Notes: Standard errors corrected for state-year clustering are reported in parentheses. The data are from the Census IPUMS for 1960 and 1970 (State Form 1), with the sample restricted to white, U.S.-born, married women of prime working age (18 to 55 years old), with state information, and working husbands. All regressions include four education dummies; a quartic in potential experience; household income (in 1970 dollars); number of children under age 5; number of children over age 5; and a full set of state and year dummies. Probit entries are estimates of the implied marginal effects on the probability of a positive outcome (labor force participation). The sample size is 322,516. ${ }^{*}$ denotes significance at the $10 \%$ level, denotes significance at the $5 \%$ level, and ${ }^{* * *}$ denotes significance at the $1 \%$ level. 
Table 5: First Stage Estimates of the Effect of Mean Appliance Ownership Rates among Singles in the State on the Appliance Ownership of Married Women

\begin{tabular}{|c|c|c|c|c|c|c|c|}
\hline & $\begin{array}{c}\text { Owns } \\
\text { Washer } \\
(1)\end{array}$ & $\begin{array}{c}\text { Owns } \\
\text { Washer } \\
(2)\end{array}$ & $\begin{array}{c}\text { Owns } \\
\text { Dryer } \\
(3) \\
\end{array}$ & $\begin{array}{c}\text { Owns } \\
\text { Dryer } \\
(4) \\
\end{array}$ & $\begin{array}{l}\text { Owns } \\
\text { Freezer } \\
(5)\end{array}$ & $\begin{array}{c}\text { Owns } \\
\text { Freezer } \\
(6) \\
\end{array}$ & $\begin{array}{c}\text { Owns All } \\
\text { Three } \\
(7)\end{array}$ \\
\hline Share of Single Women in State Owning a Washer & $\begin{array}{l}0.245^{* * *} \\
(0.034)\end{array}$ & $\begin{array}{l}0.230^{* * *} \\
(0.035)\end{array}$ & & $\begin{array}{c}0.166^{*} \\
(0.090)\end{array}$ & & $\begin{array}{l}-0.057 \\
(0.046)\end{array}$ & \\
\hline Share of Single Women in State Owning a Dryer & & $\begin{array}{l}-0.082^{*} \\
(0.045)\end{array}$ & $\begin{array}{l}0.377^{* * *} \\
(0.084)\end{array}$ & $\begin{array}{l}0.248^{* * *} \\
(0.075)\end{array}$ & & $\begin{array}{l}0.129^{* * *} \\
(0.048)\end{array}$ & \\
\hline Share of Single Women in State Owning a Freezer & & $\begin{array}{l}0.152^{* *} \\
(0.059)\end{array}$ & & $\begin{array}{l}0.380^{* * *} \\
(0.110)\end{array}$ & $\begin{array}{l}0.422^{* * *} \\
(0.082)\end{array}$ & $\begin{array}{l}0.396^{* * *} \\
(0.089)\end{array}$ & \\
\hline $\begin{array}{l}\text { Share of Single Women in State Owning All Three } \\
\text { Appliances }\end{array}$ & & & & & & & $\begin{array}{l}1.294^{* * *} \\
(0.095)\end{array}$ \\
\hline F-statistic & 51.92 & 19.72 & 20.14 & 13.40 & 26.48 & 15.86 & 187.16 \\
\hline
\end{tabular}

Notes: Standard errors corrected for state-year clustering are reported in parentheses. The data are from the Census IPUMS for 1960 and 1970 (State Form 1), with the sample restricted to white, U.S.-born, married women of prime working age (18 to 55 years old), with state information, and working husbands. All regressions include four education dummies; a quartic in potential experience; household income (in 1970 dollars); number of children under age 5; number of children over age 5; and a full set of state and year dummies. The F-statistic corresponds to the test of joint significance of the coefficients on the endogenous regressors in each model. The sample size is 322,516. * denotes significance at the $10 \%$ level, ${ }^{* *}$ denotes significance at the $5 \%$ level, and ${ }^{* * *}$ denotes significance at the $1 \%$ level. 
Table 6: 2SLS Estimates of the Effect of Household Appliance Ownership on the Labor Force Participation of Married Women

\begin{tabular}{|c|c|c|c|c|c|c|}
\hline & $\begin{array}{l}\text { 2SLS } \\
(1) \\
\end{array}$ & $\begin{array}{l}\text { 2SLS } \\
(2) \\
\end{array}$ & $\begin{array}{c}\text { 2SLS } \\
(3)\end{array}$ & $\begin{array}{c}\text { 2SLS } \\
(4) \\
\end{array}$ & $\begin{array}{c}\text { 2SLS } \\
(5) \\
\end{array}$ & $\begin{array}{c}\text { IVProbit } \\
(6)\end{array}$ \\
\hline Washer Present in the Household & $\begin{array}{c}0.300^{*} \\
(0.166)\end{array}$ & & & $\begin{array}{c}-0.363 \\
(0.377)\end{array}$ & & \\
\hline Dryer Present in the Household & & $\begin{array}{c}0.474^{* *} \\
(0.194)\end{array}$ & & $\begin{array}{c}0.663^{*} \\
(0.383)\end{array}$ & & \\
\hline Freezer Present in the Household & & & $\begin{array}{l}0.331^{* * *} \\
(0.118)\end{array}$ & $\begin{array}{c}-0.322 \\
(0.436)\end{array}$ & & \\
\hline $\begin{array}{l}\text { All Three Appliances Present in the } \\
\text { Household }\end{array}$ & & & & & $\begin{array}{l}0.261^{* * *} \\
(0.058)\end{array}$ & $\begin{array}{l}0.279^{* * *} \\
(0.054)\end{array}$ \\
\hline F-statistic & 3.26 & 5.94 & 7.90 & 1.70 & 20.14 & 26.69 \\
\hline
\end{tabular}

Notes: Standard errors corrected for state-year clustering are reported in parentheses. The data are from the Census IPUMS for 1960 and 1970 (State Form 1), with the sample restricted to white, U.S.-born, married women of prime working age (18 to 55 years old), with state information, and working husbands. All regressions include four education dummies; a quartic in potential experience; household income (in 1970 dollars); number of children under age 5; number of children over age 5; and a full set of state and year dummies. The state's contemporaneous mean appliance ownership rates among single women are used as instruments for the endogenous regressors listed on each row. The F-statistic corresponds to the test of joint significance of the coefficients on the endogenous regressors in each model. Probit entries are estimates of the implied marginal effects on the probability of a positive outcome (labor force participation). The sample size is $322,516 .{ }^{*}$ denotes significance at the $10 \%$ level, ${ }^{* *}$ denotes significance at the $5 \%$ level, and ${ }^{* * *}$ denotes significance at the $1 \%$ level. 
Table 7: Robustness Checks: Falsification Exercises

Outcome variable: Labor Force Participation of Single Women

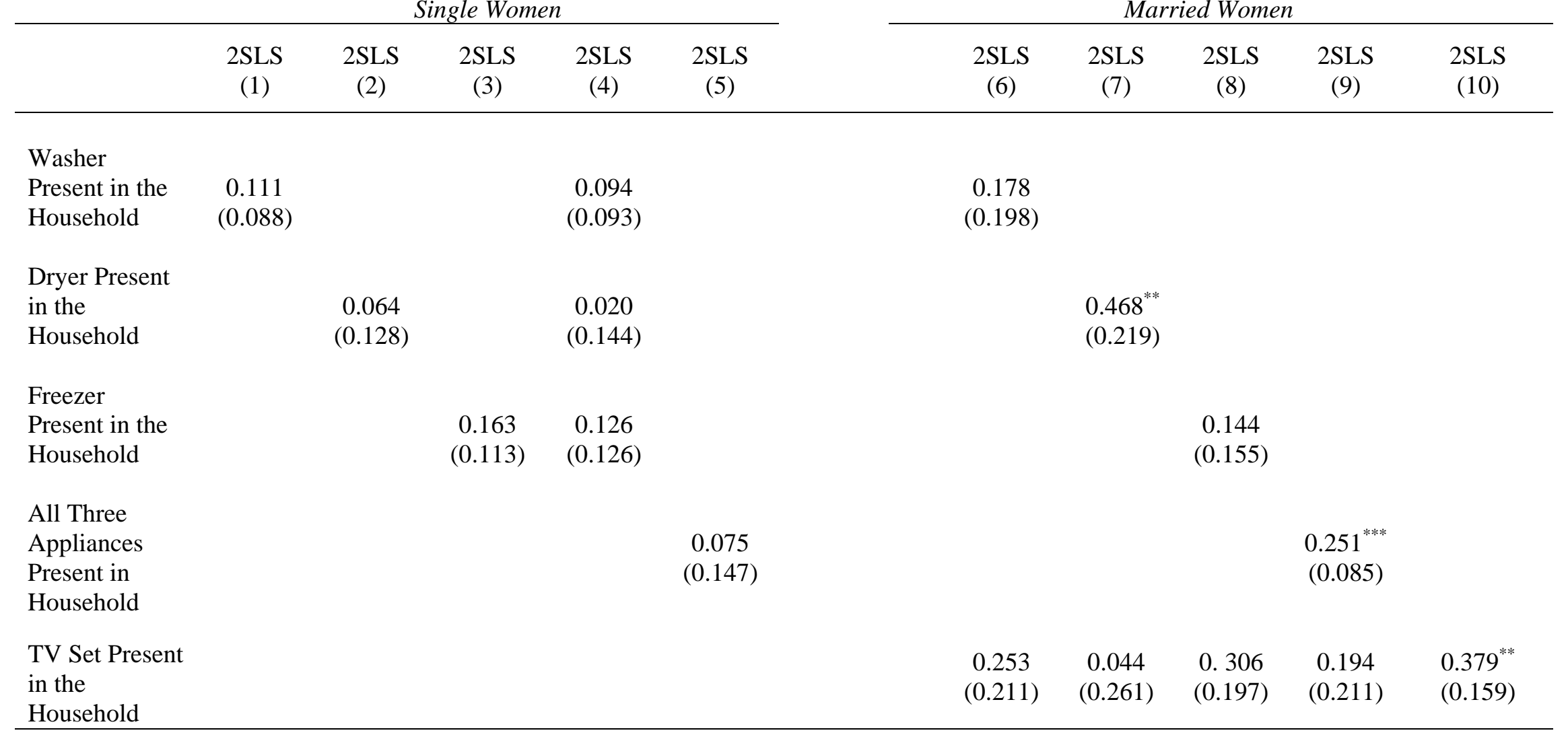

Notes: Entries are estimates of the implied marginal effects on the probability of a positive outcome (labor force participation). Standard errors corrected for state-year clustering are reported in parentheses. The data are from the Census IPUMS for 1960 and 1970 (State Form 1), with the sample restricted to white, U.S.-born, married women of prime working age (18 to 55 years old), with state information, and working husbands. The sample size is 43,984 for columns $1-5$, and 322,516 for columns $6-10$. All regressions include four education dummies; a quartic in potential experience; household income (in 1970 dollars); number of children under age 5; number of children over age 5; and a full set of state and year dummies. IV models use the state's contemporaneous mean appliance ownership rates among single women as instruments for the endogenous regressors listed on each row. ${ }^{*}$ denotes significance at the $10 \%$ level, ${ }^{* *}$ denotes significance at the $5 \%$ level, and ${ }^{* * *}$ denotes significance at the $1 \%$ level. 
Table 8: Robustness Checks

\begin{tabular}{|c|c|c|c|c|}
\hline & $\begin{array}{l}\text { 24-55 Year } \\
\text { Old Women }\end{array}$ & $\begin{array}{l}\text { Single Women } \\
\text { and Men }\end{array}$ & $\begin{array}{l}\text { Single Women } \\
\text { in the Labor } \\
\text { Force }\end{array}$ & $\begin{array}{l}\text { Gender } \\
\text { Wage } \\
\text { Gap }\end{array}$ \\
\hline & $\begin{array}{l}\text { 2SLS } \\
\text { (1) }\end{array}$ & $\begin{array}{l}\text { 2SLS } \\
(2)\end{array}$ & $\begin{array}{l}\text { 2SLS } \\
\text { (3) }\end{array}$ & $\begin{array}{l}\text { 2SLS } \\
(4)\end{array}$ \\
\hline $\begin{array}{l}\text { All Three Appliances } \\
\text { Present in Household }\end{array}$ & $\begin{array}{l}0.233^{* * *} \\
(0.053)\end{array}$ & $\begin{array}{l}0.251^{* * *} \\
(0.065)\end{array}$ & $\begin{array}{l}0.259^{* * *} \\
(0.080)\end{array}$ & $\begin{array}{l}0.270^{* * * *} \\
(0.059)\end{array}$ \\
\hline Gender Wage Gap & & & & $\begin{array}{l}-0.040 \\
(0.052)\end{array}$ \\
\hline & \multicolumn{4}{|c|}{ First-Stage Regression } \\
\hline $\begin{array}{l}\text { Share of Single Women in } \\
\text { State Owning All Three } \\
\text { Appliances }\end{array}$ & $\begin{array}{l}1.163^{* * *} \\
(0.097)\end{array}$ & $\begin{array}{l}1.593^{* * *} \\
(0.122)\end{array}$ & $\begin{array}{l}0.976^{* * *} \\
(0.203)\end{array}$ & $\begin{array}{l}1.283^{* * *} \\
(0.099)\end{array}$ \\
\hline F-statistic & 143.75 & 169.78 & 23.11 & 167.95 \\
\hline
\end{tabular}

Notes: Standard errors corrected for state-year clustering are reported in parentheses. The data are from the Census IPUMS for 1960 and 1970 (State Form 1), with the sample restricted to white, U.S.-born, married women of prime working age (18 to 55 years old), with state information, and working husbands. All regressions include four education dummies; a quartic in potential experience; household income (in 1970 dollars); number of children under age 5; number of children over age 5; and a full set of state and year dummies. The column '24-55 Year Old Women' refers to the case in which the sample of both married and single women only includes women between 24 and 55 years of age. In this case the sample size of married women is 285,037. The column 'Single Women and Men' reports results for the case in which the state's contemporaneous mean appliance ownership rates among single women and men are used as instruments for the endogenous regressor listed in the row. The column 'Single Women in the Labor Force' reports results for the case in which the state's contemporaneous mean appliance ownership rates among single women in the labor force is used to instrument for the endogenous regressor. The column 'Gender Wage Gap' reports results for the benchmark specification when the ratio of average wages of full-time year-round women workers to full-time year-round men workers in the state is added to the regressions. The sample size of married women in the last 3 columns is $322,516 .{ }^{*}$ denotes significance at the $10 \%$ level, ${ }^{* *}$ denotes significance at the $5 \%$ level, and denotes significance at the $1 \%$ level. 
Table 9: OLS and 2SLS Estimates of the Effect of Household Appliance Ownership on Employment, Full-Time and Year-Round Employment of Married Women, and Total Hours Worked Last Year

\begin{tabular}{|c|c|c|c|c|c|c|c|}
\hline \multicolumn{2}{|c|}{ Employment Previous Week } & \multicolumn{2}{|c|}{$\begin{array}{l}\text { Worked Full-Time } \\
\text { Last Week }\end{array}$} & \multicolumn{2}{|c|}{$\begin{array}{c}\text { Worked Year-Round } \\
\text { Last Year }\end{array}$} & \multicolumn{2}{|c|}{$\begin{array}{c}\text { Hours Worked } \\
\text { Last Year }\end{array}$} \\
\hline $\begin{array}{l}\text { OLS } \\
(1)\end{array}$ & $\begin{array}{l}\text { 2SLS } \\
(2)\end{array}$ & $\begin{array}{l}\text { OLS } \\
(3)\end{array}$ & $\begin{array}{l}\text { 2SLS } \\
(4)\end{array}$ & $\begin{array}{l}\text { OLS } \\
(5)\end{array}$ & $\begin{array}{l}\text { 2SLS } \\
(6)\end{array}$ & $\begin{array}{l}\text { OLS } \\
(7)\end{array}$ & $\begin{array}{l}\text { 2SLS } \\
(8)\end{array}$ \\
\hline $\begin{array}{l}0.006^{* * *} \\
(0.002)\end{array}$ & $\begin{array}{l}0.240^{* * *} \\
(0.062)\end{array}$ & $\begin{array}{l}-0.003 \\
(0.002)\end{array}$ & $\begin{array}{l}0.379^{* * *} \\
(0.055)\end{array}$ & $\begin{array}{c}0.000 \\
(0.002)\end{array}$ & $\begin{array}{l}0.220^{* * *} \\
(0.045)\end{array}$ & $\begin{array}{l}-0.313 \\
(3.879)\end{array}$ & $\begin{array}{l}552.78^{* * *} \\
(97.806)\end{array}$ \\
\hline
\end{tabular}

Notes: Standard errors corrected for state-year clustering are reported in parentheses. The data are from the Census IPUMS for 1960 and 1970 (State Form 1), with the sample restricted to white, U.S.-born, married women of prime working age (18 to 55 years old), with state information, and working husbands. The sample size is 322,516. Dependent variables: 'Employment Previous Week' is a binary indicator for whether the individual was employed in the previous week; 'Worked Full-Time Last Week' is a dummy variable indicating whether the individual worked at least 35 hours the previous week; 'Worked Year-Round Last Year' is an indicator for whether the individual worked at least 48 weeks in the previous year. 'Hours Worked Last Year' denotes a regression in which the dependent variable is represented by hours worked by a married woman in the previous year (0 if she did not work). All regressions include four education dummies; a quartic in potential experience; household income (in 1970 dollars); number of children under age 5; number of children over age 5; mean log female wages in the state and year; and a full set of state and year dummies. 2SLS models use the state's contemporaneous mean appliance ownership rates among single women as instruments for the endogenous regressors listed on each row. ${ }^{*}$ denotes significance at the $10 \%$ level, ${ }^{* *}$ denotes significance at the $5 \%$ level, and ${ }^{* * *}$ denotes significance at the $1 \%$ level. 